\title{
Mobilizing innovation for sustainability transitions: a comment on transformative innovation policy
}

By Jan Fagerberg, Centre for Technology, Innovation and Culture, University of Oslo

Email: jan.fagerberg@tik.uio.no

Web: http://www.janfagerberg.org/

Keywords: transformative innovation policy, mission-oriented policy, innovation system, climate change, sustainability, transition

\section{Highlights:}

- Discusses the role of innovation policy in sustainability transitions,

- Examines the merits of various policy approaches, e.g., mission oriented innovation policy, strategic niche management, transition management, national innovation systems and transformative innovation policy,

- Considers the lessons for the development and implementation of transformative innovation policy.

Abstract: The topics addressed in this paper concern the (much-needed) transition to sustainability and what role (innovation) policy can play in speeding up such changes. In their Discussion Paper Schot and Steinmueller (this issue) argue that the existing theorizing and knowledge bases within the field of innovation studies are "unfit" for this task and that a totally new approach is required. This paper takes issue with this claim. Policy advice, it is argued, needs to be anchored in the accumulated research on the issue at hand, in this case, innovation. The paper therefore starts by distilling some important insights on innovation from the accumulated research on this topic and, with this in mind, considers various policy approaches that have been suggested for influencing innovation and sustainability transitions. Finally, the lessons for the development and implementation of transformative innovation policy are considered. It is concluded that the existing theorizing and knowledge base in innovation studies may be of great relevance when designing policies for dealing with climate change and sustainability transitions.

Acknowledgements: The work on this paper has benefitted from economic support from The Norwegian Research Council (project no. 271917).

\section{Article history:}

Date of original submission: January 29, 2018

Date (final) revised version submitted: June 25, 2018

Date of acceptance: July 18, 2018 


\section{Introduction}

Economic growth has improved living standards, health and longevity across the globe, although the benefits have been far from evenly distributed. But it has also led to increasing pressure on scarce resources and ecosystems, and continuing on the same track for ever would definitely not be sustainable. ${ }^{1}$ In particular, the burning of fossil fuels to provide energy has (in addition to local pollution) led to growing emissions of greenhouse gases into the atmosphere and steady increases in the global temperature, with potentially very negative environmental and economic consequences in the years ahead (Stern 2015). To avoid this outcome, emissions of greenhouse gases need to be reduced to almost zero before the end of this century, a goal that almost all nations now have agreed to. ${ }^{2}$ This is a very demanding goal indeed, as $80 \%$ percent of global energy is provided through burning of fossil fuels. ${ }^{3}$ To reach this goal, extensive changes in technology, economic structure, governance, and ways of life will be required. That is why innovation - and policies supporting it - is essential for the transition to sustainability (Fagerberg et al 2016).

While it is easy to argue that innovation must play an important role in the transition towards sustainability, it is much more challenging to provide good models for how policy may help in mobilizing innovation for this purpose (Mowery et al 2010). Nevertheless, there is a growing literature using insights from innovation studies and, to a varying degree, other scientific fields to discuss how innovation policy can make a difference in this respect, employing concepts such as ecoinnovation policy (Kemp 2011) transformative innovation policy (Steward 2012) or mission-oriented innovation policy (Mazzucato 2017). Schot and Steinmueller (this issue) argue that the existing theorizing and knowledge base within the field of innovation studies is "unfit" for this task and that a totally new approach (knowledge base) is required. However, Schot and Steinmueller's disdain of the existing knowledge base on innovation arguably results in rather vague policy advice. For example, the role of firms in transformative innovation is hardly discussed, although it should be well known that the private business sector is the major source of innovation in contemporary societies, and that without their active participation pleas for transformative innovation, although well-intended, have little chance of succeeding. Arguably, this is an issue for which the received knowledge-base within innovation studies may be very relevant.

Before going into the subject matter of this paper in more detail a few clarifications may be in order. First, as is common in innovation studies (Fagerberg 2004), this paper uses the term innovation in a broad sense, i.e., including the entire process from the creation of new ideas to their implementation and diffusion in the economic and social system. This is particularly important in the context of sustainability transitions, for which changes in practice, i.e., implementation and diffusion, are essential (Mowery et al 2010). Second, this paper identifies innovation policy with policies (and policy instruments) that influence innovation in a non-trivial manner (Edquist 2004), since what matters for

\footnotetext{
${ }^{1}$ Sustainability can be defined very broadly, as in the seventeen sustainable development goals (SDG) agreed to by the United Nations (http://www.un.org/sustainabledevelopment/sustainable-development-goals/), or more narrowly as the ability of the economy to "function within the capacity provided by the earth's ecosystems" (Dietz and O'Neill 2013, p. 46). However, the latter is obviously of vital importance for the former. ${ }^{2}$ The Paris climate agreement (or convention) was adopted by consensus between 196 parties at the $21^{\text {st }}$ Conference of the United Nations Framework Convention on Climate Change (UNFCCC) in Paris on 12 December 2015. As of December 2017171 parties have ratified the convention (http://unfccc.int/2860.php). ${ }^{3}$ See https://data.worldbank.org/indicator/EG.USE.COMM.FO.ZS, addressed on November 30, 2017.
} 
achieving real progress with respect to the transition to sustainability is a policy's impact, not its label. This means that a range of sectoral policies which are important for innovation (and sustainability transitions) but that are (mainly) carried out for other purposes become very relevant (Fagerberg 2017). It also raises important questions with respect to governance, coordination and direction of policy, which (as we shall see) have been central to innovation policy discussions for some time, but that arguably become of even greater relevance for the ability to carry out the more ambitious transformative policies that contemporary challenges require. Third, it is important to distinguish between innovation policy practice on the one hand and theories - or frames - used to understand, develop and justify it (which is the main focus of Schot and Steinmueller, this issue)on the other hand. In fact, the term innovation policy is fairly recent, dating back to around 1980 (Rothwell 1982), and the same goes for dedicated theorizing about it (see Fagerberg 2017). However, innovation policy practice (as defined in this paper) has a much longer history, although as Boekholt (2010) explains, earlier on such policies were usually motivated by other aims and carried other labels (e.g., science, defence, health, industrial policy). Kemp (2011) similarly classifies innovation policies during this period as "mission-led support for military technologies and civil engineering technologies" (ibid, p.2). A relevant question, which will be considered in the next section, is to what extent there are important lessons from these early experiments with mission-oriented policy for how to deal the complex grand challenges facing policy makers today (see e.g., Mazzucato 2013).

The paper starts, in the next section, by distilling some important insights on innovation from the accumulated research on this topic ${ }^{4}$ and, with this in mind, considers various policy approaches that have been suggested for how to mobilize innovation in the pursuit of broader societal goals (such as sustainability transitions). The final section sums up the lessons for the development and implementation of transformative innovation policy.

\section{Innovation, sustainability transitions and policy}

Innovation was for a long time a neglected topic in mainstream social science. The main exception to this rule was the Austrian-American economist Joseph Schumpeter, who already a hundred years ago developed an original theory of innovation as the driving force of long run economic and societal change. ${ }^{5}$ The main focus was, just as in some of the more recent work on sustainability (e.g., Daly 2008), not on economic growth per se but on qualitative changes in the composition of output, the organization of economic activities, and the structure of the economy. Schumpeter made a sharp distinction between invention, i.e., new ideas for how to do things, and innovation, that is, the ability to carry these out in practice, because:

\footnotetext{
${ }^{4}$ For broader overviews of the knowledge-base on innovation see Fagerberg et al (2004), Hall and Rosenberg (2012) and Fagerberg et al (2012).

${ }^{5}$ Schumpeter's main works were "The theory of economic development", published in German in 1912 and in a revised English edition in 1934, and "Capitalism, Socialism and Democracy" from 1942. For a brief introduction to Schumpeterian theory and its subsequent application by others see Fagerberg (2003).
} 
"As long as they are not carried out into practice, inventions are economically irrelevant. And to carry any improvement into effect is a task entirely different from the inventing of it, and a task, moreover, requiring entirely different kinds of aptitudes." (Schumpeter 1934, p. 88).

According to Schumpeter innovation comes in many different shapes, e.g., not only technological but also organizational, and different sizes, ranging from very radical innovations, such as railways, electricity or use of fossil fuels as a power source, that might totally revolutionize the society and the economy, to minor changes in existing products and processes. He also provided us with a theory of innovation as "new combinations". Hence, what is new is not necessarily the constituent parts but the way they are put together. Thus, contemporary innovation is influenced by innovation in the past, just as today's innovation activities contribute to shape future innovation paths. ${ }^{6}$ In this combinatory dynamics, the innovative firm draws on various resources such as knowledge, skills, and finance, and its possibility to succeed critically depends on being able to mobilize these resources. The innovative firm also depends on the institutional framework into which it is embedded, and - not the least - on whether there is a market for its innovations: Innovations that are not sufficiently appreciated by potential customers, that is, are selected against, are doomed to failure. Moreover, these various factors generally are complements rather than substitutes.

There are important lessons from this, not only for firms (that tend to learn this the hard way), but also for policy-makers that wish to encourage innovation. That is, to succeed with innovation support it is not sufficient to focus one particular resource, say knowledge, because there may be other constraints that are equally or more relevant. Thus, a holistic perspective on innovation, focusing not only on supply but also demand factors, is essential for success in innovation policy (Boekholt 2010, Edquist 2004, Edler and Georghiou 2007, Edler and Fagerberg 2017, Kemp 2011).

\section{Supporting radical innovation}

One of the most salient features of radical innovation is that it takes time, often several decades if not more. As Nathan Rosenberg and Stephen Kline explain:

"... most important innovations go through drastic changes in their lifetimes - changes that may, and often do, totally transform their economic significance. The subsequent improvements in an invention after its first introduction may be vastly more important, economically, than the initial availability of the invention in its original form" (Kline and Rosenberg 1986, p.283)

Hence, as they point out, the first versions of an innovation are often unpractical, costly devises that have problems in reaching out to customers in large numbers. History is replete with examples, e.g., when the first cars appeared towards the end of the 1800s they were generally regarded as expensive (and unreliable) toys for the rich. Moreover, the first computers, appearing about half a century later, were extremely large, expensive and with little computing power compared to, say, a present-day smart phone, and therefore with very limited market appeal except for the US military and a few other customers. Similarly, when solar cells were invented in the 1950s, they were very costly compared to other ways to generate energy and attracted little commercial interest except after a while - for use in the US space missions (Jacobsson et al 2004). Thus, as in many other cases the creation of a niche market turned out to be essential for developing the innovation (e.g,

\footnotetext{
${ }^{6}$ This may give rise to innovation paths or trajectories influencing innovation activity and economic development for considerable periods of time (Dosi 1982, Freeman et al 1982, Freeman and Louçã 2001).
} 
increasing performance and reducing costs through learning and economies of scale) so that it eventually would get broader acceptance.

It is not surprising, therefore, that the creation and support of such niches have been recognized as useful tools by policy-makers that wish to support the development of a specific innovation (or innovations for a specific purpose). Particularly in the US such "mission-oriented" policies (Ergas 1986) have been carried out with great vigour by, say, military, space and health agencies (Mowery 2011) and many important innovations that eventually would have a large economic and societal impact have benefitted from these efforts (Mazzucato 2013). Support of niche-markets may thus be considered as a possible way forward in sustainability transition (e.g., strategic niche management, ${ }^{7}$ see Kemp et al 1998). However, mission-oriented policies (or strategic niche management) require very capable policy makers (or managers) and stringent procedures to avoid the many traps that such a project easily may fall into. These include e.g., aborting the project too early; premature lock-in to a specific technological trajectory (before the pros and cons of various alternatives have been properly explored); or capture by special interests (within the private business sector for example). As Dani Rodrik $^{8}$ explains, insulating the innovation project from relevant private actors (as some might suggest) is clearly not a good idea, as it would reduce access to critically important knowledge and hamper the learning that the project was intended to achieve. Nevertheless, it is vital that the autonomy of government is retained through appropriate policy design. Rodrik suggests that a design emphasizing clear goals/targets that are enforced; transparency; and accountability may go a long way in doing so.

While potentially a very powerful tool, most successful examples of past mission-oriented policies (see, e.g., Mowery 2011, Mazzucato 2013) refer to cases where a single public agency both finances the project and is the final user. However, as Mowery et al (2010) point out, transforming the economy to sustainability is a much more complex task, involving multiple technologies, extensive structural change and a large number of users within or across sectors. Hence, as they suggest, to discuss these matters a broadening of the perspective from entrepreneurial dynamics within niches to what happens at the meso and macro levels may be required.

\section{Changing (technological) regimes}

The role of large, established firms in existing sectors for innovation and diffusion became one of the most central issues in post-war innovation studies. In a series of works, culminating with the book "An evolutionary theory of economic change" from 1982, Richard Nelson and Sidney Winter outlined a novel theory on the matter that eventually became very influential. ${ }^{9}$ According to Nelson and Winter the central competitive asset of large firms is the organizational knowledge they posit,

\footnotetext{
${ }^{7}$ Kemp et al (1998, p. 186) defines it as follows: "strategic niche management is the creation, development and controlled phase-out of protected spaces for the development and use of promising technologies by means of experimentation, with the aim of (1) learning about the desirability of the new technology and (2) enhancing the further development and the rate of application of the new technology"

${ }^{8}$ Rodrik uses the term "green industrial policy" for policies that arguably might equally well have been characterized as green innovation (or technology) policy. He defines it as policies that "stimulate and facilitate the development of green technologies" (Rodrik 2014, p. 488).

${ }^{9}$ Nelson and Winter (1982) is the most cited work in innovation studies (Fagerberg et al 2012) and is also very popular among management scholars but receives much less attention in economics proper (Meyer 2001).
} 
consisting of a set of routines for action that is reproduced (and adjusted) through practice. As a result, large, established firms are path-depended creatures and

" much better of the tasks of self-maintenance in a constant environment than they are of major change, and much better in changing in the direction of "more of the same" than they are at any other kind of change"(Nelson and Winter 1982, p. 9-10).

Thus, large firms in established sectors are analysed as highly efficient but rather inert organizations working under a common umbrella, a "technological regime" (Winter 1984), reflecting a common understanding of "how things are done" in the sector. It follows that for entrants to question such established routines and compete with the incumbents may be quite challenging indeed.

This perspective has been adapted to the analysis of sustainability transitions by Arie Rip and Rene Kemp (Rip and Kemp 1998) and other (mainly Dutch) scholars (e.g., Geels 2002, 2015, Geels and Schot 2007) under the label "multi-level perspective" (MLP). ${ }^{10}$ Three levels are highlighted in the analysis: the macro-level (labelled "landscape") which is assumed to change slowly and for reasons that may be seen as "exogenous"; the meso-level, which is dubbed "technological" (or alternatively - "sociotechnical") regime; ${ }^{11}$ and the micro-level, the "niches", which is where the development of radical new technologies - the experimentation - is assumed to occur. However, a new, radical technology, even if successful in a narrow technological sense, also needs to be accepted by the broader regime structuring the relevant part of the economy, and this is seen as challenging due to the assumedly inert nature of such regimes. Therefore, much of the focus in this literature has been on the conditions under which such new, radical technologies, developed in niches, can become more broadly accepted and eventually contribute to regime change in, say, a more sustainable direction. ${ }^{12}$

Out of these concerns emerged an innovative policy approach, labelled "transition management" (Rotmans et al. 2001, Kemp et al 2007, Loorbach 2010), for how to address complex policy challenges of a long-term nature (such as sustainability transitions), challenges that arguably do not get the attention they deserve due to the short-term focus of traditional politics (e.g., electoral cycles). It does so by creating a separate space - a transition arena (or platform) - with the purpose of transforming general policy goals into concrete visions, which in turn are used to develop possible transition paths for how to connect the present with the future. A transition arena should according to Loorbach (2010) be led by a small number of so-called "frontrunners", i.e., very capable and motivated people that participate in a personal capacity but with a background from "the societal pentagon: government, companies, NGOs, knowledge institutes, and intermediaries" (ibid, p.174). To explore the transition paths and facilitate learning practical experiments (e.g, strategic niche

\footnotetext{
${ }^{10}$ This has given rise to a burgeoning literature, for overviews see e.g., Smith et al. (2010) and van den Bergh et al. (2011).

${ }^{11}$ Rip and Kemp define "technological regime" as follows: "A technological regime is the rule-set or grammar embedded in a complex of engineering practices, production process technologies, product characteristics, skills and procedures, ways of handling relevant artefacts and persons, ways of defining problems - all of them embedded in institutions and infrastructures" (Rip and Kemp 1998, p. 338). Geels (2002) suggests the notion "sociotechnical regime" for the same phenomenon.

12 The interaction between the regime and the landscape levels, e.g., how differences in the pressure for change at the macro level may influence regimes and, depending also on the underlying technological dynamics, open up for different "transition pathways" is discussed by Geels and Schot (2007).
} 
management) are suggested. Continuous monitoring and evaluation are recommended to encourage policy learning (Voss et al 2009, Loorbach 2010).

The approach was adopted by Dutch policy-makers in 2002 under the auspices of the Ministry for Economic Affairs and a number of transition platforms, composed of individuals from the private and public sector, academia and civil society, were established focusing on various issues of relevance for the transition to sustainability. The process resulted among other things in a "transition action plan", containing ambitious goals for e.g. cuts in greenhouse-gas emissions and improvements in energy efficiency, as well as a number of concrete initiatives aimed at supporting the transition in various ways. It also led to closer cooperation between different parts of government (Nill and Kemp 2009). However, the approach has been criticized for being overly technocratic and for paying too little attention to democratic processes (Hendriks 2009, Schmitz 2015). Moreover, in practice transition management in the Netherlands proved vulnerable to capture by incumbent interests from the established oil and gas industry (Smith and Kern 2009). In 2011, following the formation of a new and more conservative government, the program was formally terminated (Kemp and Never 2017). Arguably, what this shows is, as Voss et al (2009) point out, that in a democracy there is no escape from the need for strong support from the broader polity for pursuing radical change at the societal level through dedicated policy arrangements.

\section{Adapting to technological revolutions}

As already pointed out by Schumpeter (Schumpeter 1939), radical innovations differ with respect to how pervasive their economic effects are. While some radical innovations may influence a specific sector or industry only, others may affect a whole range of sectors or, in rare cases, the entire economy. Christopher Freeman and Carlota Perez use the term "technological revolutions" (or alternatively - "changes in techno-economic paradigm") for "changes in technology systems (that) are so far reaching in their effects that they have a major influence on the behaviour of the entire economy" (Freeman and Perez 1988, p. 46-7). The defining feature of a technological revolution, they argue, is the existence a cheap key input characterized by rapidly declining costs, almost unlimited supply and very broad applicability, such as oil during much of the twentieth century and microelectronics more recently. However, according to Freeman and Perez, for such path-breaking innovation to come to (full) fruition, a number of complementary factors need to be in place, not only in the form of an appropriate infrastructure (although that may be essential), but also with respect to the economic, organizational and institutional set up of society. Nevertheless, since such factors take time to develop, a mismatch between the requirements of an emerging technological revolution and the existing socio-economic framework is likely, and this may significantly slow down the diffusion of the new technological revolution (and hamper its potential beneficial effects). It follows that the capacity of a country to undertake appropriate changes may be of vital importance for its ability to exploit the potential offered by an emerging technological revolution.

While this perspective has hitherto mainly been used to analyse past transformations, it relevance for the present, and particularly the growth of renewable energy, has received increasing attention in recent years (Pearson and Foxon 2012, Mathews 2013, 2014, Stern 2015). In fact, for both wind and solar the costs of producing electricity has diminished year by year (i.e. productivity has increased) as output has expanded (Figure 1). As a result cost-levels for renewables now are substantially lower than those of e.g., nuclear energy plants (Seba 2014), and - in many if not most locations world-wide 
- on pair with or below plants producing electricity by burning fossil fuels (Goodall 2016) even when the social costs associated with greenhouse gas emissions are not accounted for. This pattern is as several observers have pointed out reminiscent of previous technological (industrial) revolutions.

Figure 1 A technological revolution in the making?

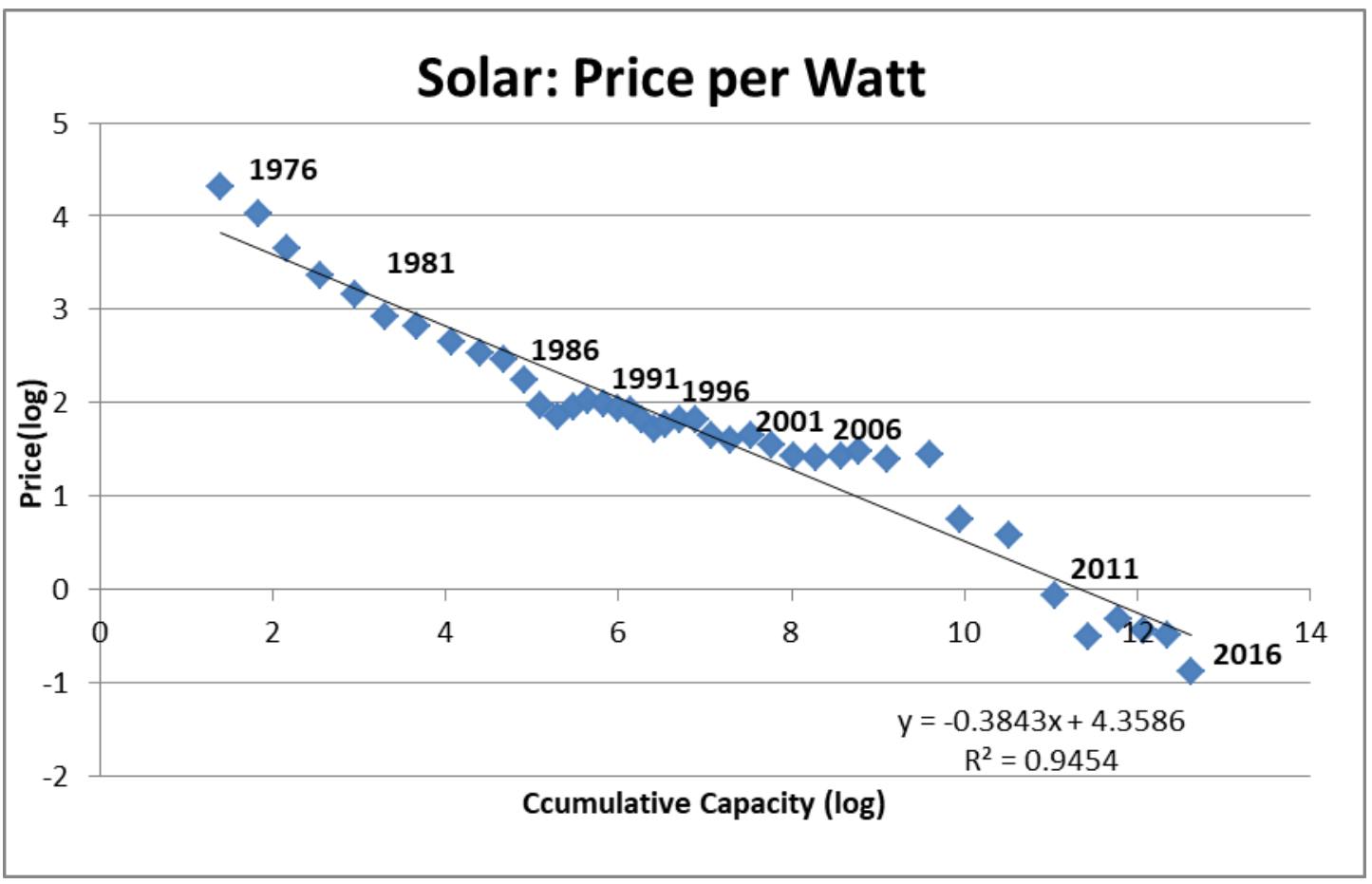

Note: "Price per watt" is the average price of a photovoltaic (PV) module (in real 2016 US dollars) divided by its rated DC output power in watts. "Cumulative capacity" in a specific year is the sum of the rated DC output power in watts of all PV modules produced prior to that year (starting in 1976). The regression underlying the trend-line is included in the lower right of the figure. Source: Own calculations based on data from Bloomberg New Energy Finance (with contributions from IEA and Paul Maycock).

A global energy-system based on renewables, particularly wind and solar, would mean that the whole world will have to go electric. For example, the entire transport-sector - a major emitter of greenhouse-gases world wide - would have to be electrified, either battery-driven or by using fuels derived from renewable energy. A severe challenge, though, in an energy system based on renewables is what to do when the wind doesn't blow and/or the sun doesn't shine? To alleviate such problems energy-storage facilities and management systems would have to be improved, and this is currently a hot area for innovation world-wide.

The prospect of a renewable energy revolution raises several interesting questions for policy. In particular, can the transition happen in time, so that the most damaging effects of climate change may be avoided? Energy research has shown that previous energy transitions have taken several decades if not more to unfold (Wilson 2012, Smil 2016), but also that change may occur much faster when advantages for end-users are sufficiently large (Grubler 2012, Pearson and Foxon 2012) and/or there are proactive policies in place (Sovacool 2016). 
Transforming innovation systems: The role of (innovation) policy

In the aftermath of the OPEC oil crisis in the 1970s, the global economy entered a long period of slow growth, structural problems and unemployment. Traditional economic policies appeared to have little effect. It was in this context that a perspective focusing on innovation as the source of economic change, innovation systems as frameworks for shaping such dynamics (Freeman 1987, Lundvall 1992, Nelson 1993), and innovation policy as the main tool for influencing it (Rothwell 1982), started to gain currency among policy makers. This perspective - and the associated concept "national innovation systems" ${ }^{13}$ - quickly became quite popular, not the least through the involvement of the OECD, ${ }^{14}$ which adopted it in its analyses and evaluations of innovation policies in member-states. ${ }^{15}$

A defining feature of modern innovation research is the insistence on seeing innovation as a social phenomenon, in which many different assets are combined, and a variety of actors, both inside and not the least - outside the innovative firm, take part and influence the outcome. The innovation system approach is informed by this perspective and a host of empirical research ${ }^{16}$ from the $1970 \mathrm{~s}$ onwards, highlighting the importance for successful innovation of continuous interaction between firms and their environments (e.g., customers, suppliers, various public and/or private sector organisations etc.). This led to a strong focus on the possibilities for vitalizing the system through improved interaction between its constituent parts, for example by identifying and dealing with factors hampering such interaction (Bergek et al 2008) or by improving the capabilities of system actors (including those of the policy makers themselves, see e.g., Edler and Fagerberg 2017).

Another central characteristic of the approach, consistent with its Schumpeterian origin, is a strong historical focus. National innovation systems are seen as developing over time through interaction between central economic actors, i.e., important industries and firms on the one hand and the broader "knowledge infrastructure" and political system in which they are embedded on the other hand (Fagerberg et al 2009). However, since countries specialize in different economic activities (with different needs for support etc.), and political systems differ too (for, say, historical reasons), such national systems may end up looking rather different. For example, there are large differences between otherwise quite similar countries when it comes to character of the public "knowledge infrastructure" and its interaction with the private sector (Fagerberg 2016). Such structural differences should not necessarily be regarded as a problem for policy-makers, though, as different set ups may well be equally efficient (Fagerberg 2004, 2017). Arguably, it is only through a concrete analysis of the dynamics of a system that it is possible to identify issues that require policy makers' attention (Edquist 2011).

\footnotetext{
13 The innovation system approach can be applied at different levels of aggregation, e.g., a specific technology (technological innovation systems, see Bergek et al. 2008), the sector or industry level (sectoral innovation systems, see Malerba 2004), the regional level (regional innovation systems, see Asheim and Gertler 2004) and, finally, the national level, which is the main focus here. For an overview and discussion see Edquist (2004).

${ }^{14}$ See, e.g., OECD (1997, 1999, 2002).

${ }^{15}$ For information on "OECD Reviews of Innovation Policy" see http://www.oecd.org/sti/inno/oecdreviewsofinnovationpolicy.htm.

${ }^{16}$ E.g., Freeman (1974), von Hippel (1988), Levin et al (1987) and, not the least, the European Union's Community Innovation Survey (CIS), conducted regularly from the early 1990s onwards, for an overview see Smith (2004).
} 
Nevertheless, despite such (historically produced) differences in system architecture, what goes on in such systems, i.e., the various processes a system entails, may have a lot in common. Therefore, the exploration of how such processes interact in shaping the dynamics of the national innovation system has become a central focus in recent scholarly work in this area (Liu and White 2001, Edquist 2004, Bergek et al. 2008, Fagerberg 2017). ${ }^{17}$ The implications of this for policy may usefully be discussed in relation to Figure 2, which links the output of the national innovation system, called "technological dynamics", to five generic processes influencing it, labelled knowledge, skills, demand, finance and institutions, ${ }^{18}$ i.e., the same as emphasized in our earlier discussion of firm-level innovation. In the Figure, the influences of these processes on the technological dynamics are indicated by solid arrows, while the possible feedbacks from this dynamics on the generic processes themselves are represented by dotted arrows. ${ }^{19}$ However, as indicated in the right half of the Figure, these processes are also influenced by policy-makers in a multitude of ways. ${ }^{20}$ For example, several ministries (research, education, health, industry etc.) usually engage in supporting the provision of knowledge in areas of relevance for their mandate, and similar examples may to a varying degree be found for other processes. Although many of these policies are not dubbed "innovation policies", and have traditionally not been regarded as such either, their effects on innovation may be much more important than those of more narrowly defined "innovation policies".

\footnotetext{
${ }^{17}$ In this literature, the factors influencing innovation have invariably been called activities, processes or functions, here the term "processes" will be used. The number and description of these processes differ somewhat across the different applications, to some extent related to differences in focus, but the five processes identified here are always included in one way or another. See Edquist (2004) and Bergek et al (2008) for further details.

${ }^{18}$ The dynamics of the system is as the Figure shows also influenced by interactions with the outside world, i.e., the global system in which national systems are embedded, but we are not going to dwell on this (arguably very important) aspect here, since the focus of our discussion is on national policy.

${ }^{19}$ An example of such feedback could for example be an increase in the demand for certain types of skills in an area characterized by strong innovation and growth.

${ }^{20}$ The framework also allows for a possible feedback from the dynamics of the system on policy-making (dotted line).
} 
Figure 2. The National Innovation System: Dynamics, processes and policy

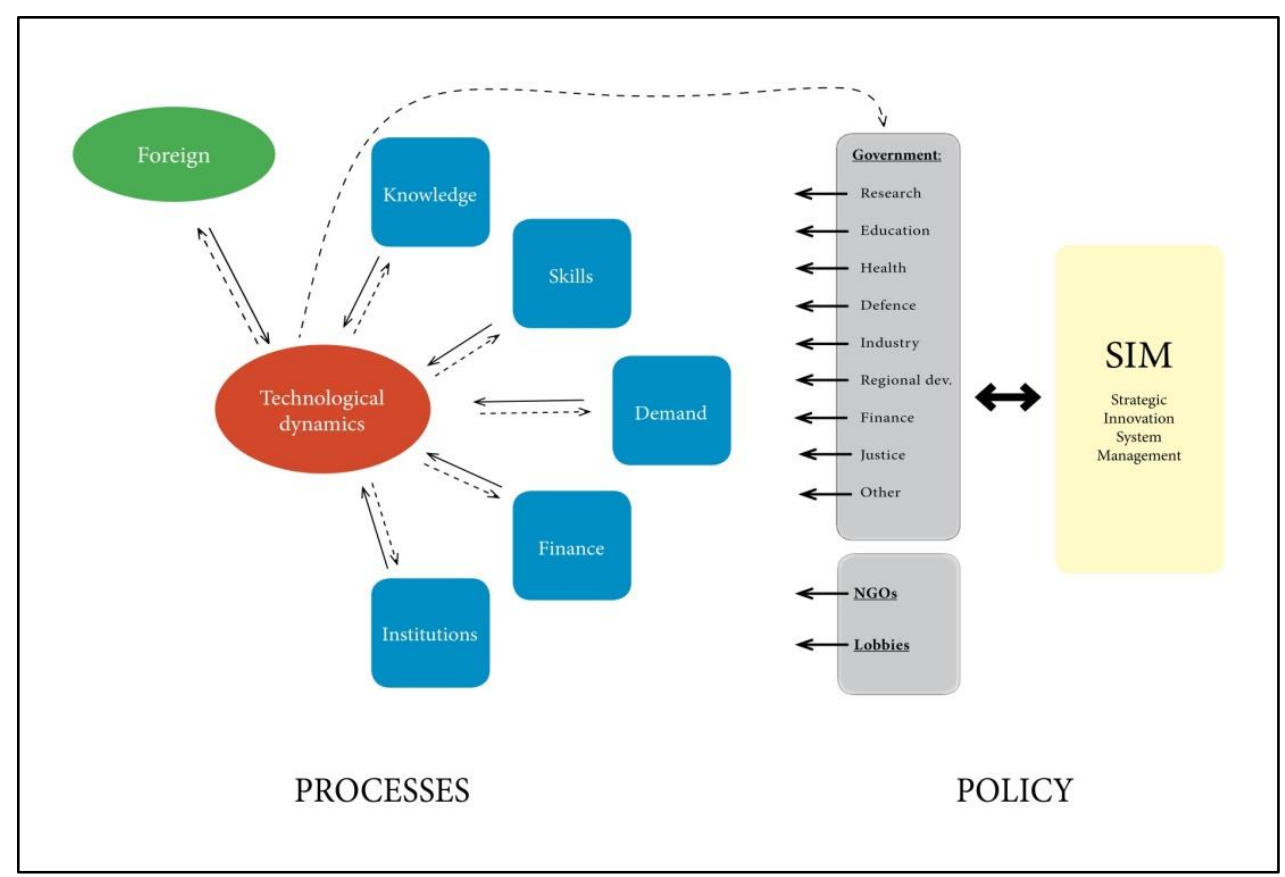

Source: Fagerberg (2017)

However, since many of these policies do also (or mainly) have other motives (energy security or public health, for example), they are not necessarily aligned with other policies influencing innovation. Therefore, there is no guarantee that the total portfolio of policies influencing innovation is designed so that the system as a whole gets the most out of its efforts. Hence, to make innovation policy into the powerful instrument that a successful transition requires, innovations in innovation policy governance and instrumentation may be necessary (Smits and Kuhlmann 2004). For example, policy coordination (Braun 2008, OECD 2010a,b), what in the Figure is called "Strategic Innovation System Management" (SIM), emerges an important (albeit demanding) ${ }^{21}$ part of innovation policy. One attempt in this direction, pioneered in Finland (Pelkonen 2006, Fagerberg 2016) and subsequently tried out in other countries as well, consists of establishing so-called innovation councils, typically with the prime minister in a leading role and involving major public and private actors in the deliberations (Serger et al. 2015). Such coordination (or alignment) of public policies across different sectors and levels may also give policy makers an opportunity to take into account strategic, long run goals for society's development, such as transforming society to sustainability. Arguably, what would be required is, as pointed out in a number of recent scholarly contributions ${ }^{22}$, to give national innovation policy a clear direction (Box 1$).^{23}$

\footnotetext{
${ }^{21}$ See, e.g., the discussion of this topic in Flanegan et al (2011).

22 See, e.g, Steward (2012), Mazzucato and Perez (2015), Mazzucato (2016, 2017), Schot and Steinmueller (this issue).

${ }^{23} \mathrm{An}$ interesting attempt of doing so is the "Green Growth National Strategy" adopted in South Korea from 2009 onwards (Mee Lie 2017).
} 


\section{Box 1 The fuzz about failures}

The dominant approach in economics today, neoclassical economic theory, is based on the belief that free ("perfect") markets generally provide the best outcome. However, it is acknowledged that if market imperfections lead to sub-optimal outcomes, so called market-failures, tilting the economy closer to the optimal state through appropriate policies may be justified. One example of such market failure concerns so-called public goods, i.e., something that everybody can use as much as they want without paying for it, making the provision of such goods unattractive for private actors and hence justifying intervention by the government. Arrow (1962) suggested that this holds for production of knowledge.

However, while the public good/market failure argument perhaps may hold for basic science (in e.g, universities), its relevance for firm-level knowledge, much of which is "sticky" (von Hippel 1994) and not easily copied, is much less obvious (Rosenberg 1990, Soete and Arundel 1993, Fagerberg 2017). Still, the failure terminology has become quite popular and has been adopted even by scholars not sharing the neoclassical framework, e.g., so-called "system failure" (Metcalfe 2005). A recent example is Weber and Rohracher (2012) who identify no less than twelve different "failures" with the hope that this intellectual effort will, as they phrase it, contribute to "legitimizing research, technology and innovation policies for transformational change" (ibid, p. 1037).

But why focusing so much on failures and not, say, on what the state is able to accomplish? Mariana Mazzucato criticizes the neoclassical approach for seriously underestimating the state's role "for actively shaping and creating markets and systems, not just fixing them; and for creating wealth, not just redistributing it "(Mazzucato 2017, p. 15). The proof of this comes according to Mazzucato from the US experience with so-called mission-oriented policies, such as putting a man on the moon, policies that were not only successful with respect to their more immediate aims, but also created a range of radical innovations that fuelled growth in the private sector for decades afterwards (Mazzucato 2013). Such missions, that is innovation policies with a clear purpose (direction), carried out (as in the US) by a network of public agencies with a considerable degree of independence, may according to Mazzucato also be highly relevant in dealing with the more complex grand challenges facing contemporary societies.

Elinor Ostrom also criticizes the neoclassical approach for underestimating the potential of actors (including policy makers) at different levels to cooperate constructively in the solution of collective challenges. She argues that many collective action problems are dealt with through cooperation between multiple actors (or agencies) at different levels that "trust one another and ...(are) willing to take on agreed action that adds to their own short term costs because they do see a long-term benefit for themselves and others " (Ostrom 2010, p. 551). Because of the large number of actors all over the world that necessarily will have to take part, Ostrom holds this "polycentric" approach to be relevant for dealing with the climate challenge (see also Smith 2017). 


\section{Conclusions}

The global economy is on an unsustainable course, and this needs to be changed, as almost all countries in the world have agreed to. Innovation and policies influencing it are arguably key resources for succeeding with this aim and, as the discussion in this paper shows, the knowledge base in innovation studies provides us with a useful framework for discussing how to make innovation policy more effective in dealing with the challenges that arise. This final section sums up the lessons of our discussion in the form of five recommendations that are important for effective innovation policy making in general and for the more ambitious transformative policies in particular:

\section{Setting direction}

In a global perspective there is no lack of talent, knowledge and resources for succeeding with transformative innovation (Mazzucato and Perez 2015, Perez 2016). Rather the problem is how to mobilize these assets. Many firms, particularly large ones, are reluctant to move into new areas because they are uncertain about the future prospects. One of the most effective policy instruments that innovation policy makers can use to remedy this problem is to influence firms' expectations about the future, that is, setting direction (Mazzucato 2017). Previously this was regarded as an almost unsurmountable problem for policy makers, however, more recently the long-run goal of transforming the economy to sustainability has become broadly accepted. This arguably gives policy makers a golden opportunity to provide a firmer direction for society's collective innovation journey, for example in the form of a vision (or common perception) for society's long run development, which may function as a soft coordination device for the many actors, including policy makers at different levels, that need to align their actions if the transition is going to succeed. It can be made more concrete by setting targets that can be monitored and used to assess to what degree society's performance is in line with the long run goals. ${ }^{24}$ However, if this is going to work as intended (and avoid being victim to, say, shifting parliamentary majorities and changes of government), it essential that policy makers avoid the temptation to develop such a vision behind closed doors, but engage in a broad, open and transparent dialogue with stakeholders at different levels of society.

\section{Embracing opportunity}

It is common to regard sustainability transitions as implying huge costs to society. However, green innovation, i.e., new and better ways of doing things that are environmentally benign, may also save costs. Hence, the transition to sustainability is not necessarily a zero-sum game. This is so because new radical technology also offers significant opportunities. Arguably, the ongoing technological revolution in renewable energy, in combination with other changes (e.g., the continuing ICT revolution), ${ }^{25}$ may provide humanity with many the means needed to escape its current dependence on burning fossil fuels. Following this trajectory will require a lot of innovation and experimentation in areas such as energy storage and distribution, energy use (including savings), electrification of transport and so on, as well as in business models, in the organization and activities of the public sector, and in ways of life more generally. Thus, by embracing the opportunities offered by the renewable energy revolution it may be possible for policy makers to encourage (green) innovation,

\footnotetext{
${ }^{24}$ See Geels $(2014,2015)$ for a discussion of the need for policy to not only support the growth of new, green sectors but also actively reduce the old, polluting ones.

${ }^{25}$ See Perez 2002, 2016.
} 
increase productivity, create new jobs ${ }^{26}$ and significantly speed up the transition to a sustainable economic system.

\section{Mobilizing}

The collective innovation journey towards a sustainable economic system crucially depends on the active participation of numerous actors in different sectors, levels of the society and parts of the globe $^{27}$ (Mowery at al 2010). Not the least will the ability to mobilize the private business sector in transformative innovation be essential for the outcome, as pointed out above. Nevertheless, one of the most salient features of modern societies is that users are highly knowledgeable and resourceful, and that their active participation is a vital ingredient in successful innovation (Lundvall 1988, von Hippel 1988, 2005). For example, the very rapid progress in renewable energy technologies that we have witnessed in recent years would not have been possible without the active involvement of users, interest-groups and other stakeholders (Fagerberg 2018, Kuhlmann and Rip 2018). Thus, reaching out to stakeholders (including the broader public) and engage them in the collective innovation journey towards a sustainable economic system may not only be more democratic but also more effective.

\section{Holistic policy making}

Successful innovation depends on the ability to access and combine a number of different factors, such as knowledge, skills, finance, institutions and demand. Having access to one such factor, knowledge for example, is of little help if for example finance is not accessible or demand not present. Hence, he factors influencing successful innovation are for the most part complementarity in nature. That is why a holistic perspective on innovation policy making, taking into account not only a few but all factors influencing innovation, is a must if policy is going to reach its aims. The traditional supply-orientation of research and innovation policies, which still dominates in many settings, is arguably totally deficient and needs to be replaced by a broader, more holistic approach employing a wider set of policy instruments that among other things takes the crucial role of demand for innovation more properly into account (Edler and Georghiou 2007, Boon and Edler 2018). It is noteworthy that some of the most successful examples of sustainability transitions in recent years have been associated with extensive application of demand-oriented instruments (Fagerberg 2018).

\section{Improving governance}

The transition to sustainability does not only requires innovations in the economy, innovations in governance are also needed (Edler and Fagerberg 2017). As pointed out previously, since policymakers in many different settings (and levels) influence the various factors that matter for innovation, better coordination and alignment of policies are required, so that the various activities those policy-makers engage in complement rather than counteract each other. This is not a new insight, already Rothwell (1982) - in one of the first scholarly contributions on innovation policy emphasized this point. However, the higher stakes associated with the transition to sustainability

\footnotetext{
26 "Project-level data indicates that, on average, renewable energy creates more jobs than fossil-fuel technologies. Solar PV, for instance, creates more than twice the number of jobs per unit of electricity generation compared with coal or natural gas." (Irena 2017, p. 6)

${ }^{27}$ See Smith (2017) and Schmitz and Lema (2015) for treatments of the international aspects of the transition to sustainability.
} 
make the need for effective policy coordination even more acute. Moreover, the scale of the challenge, and the many actors involved, means that such coordination, to deliver on its aims, may have to extend beyond government to other stakeholders (Kuhlmann and Rip 2018). Furthermore, the ability to use innovation policy proactively to support transformative innovation also requires very competent public agencies that are able to learn from practice. Such capabilities cannot be taken for granted but needs to be actively nurtured.

\section{References}

Arrow, K. (1962) "Economic Welfare and the Allocation of Resources for Innovation," in Nelson R. R. (ed.) The Rate and Direction of Inventive Activity, Princeton: Princeton University Press, p. 609-625

Asheim, B. and Gertler, M. (2004) “The Geography of Innovation" in Fagerberg, J., Mowery, D., Nelson, R. (Eds.), The Oxford Handbook of Innovation. Oxford: Oxford University Press, p. 291-317

Boekholt, P. (2010) "The Evolution of Innovation Paradigms and their Influence on Research, Technological Development and Innovation Policy Instruments", in Smits, R., Kuhlmann, S. and Shapira,P. (eds.): The Theory And Practice Of Innovation Policy - An International Research Handbook, Cheltenham: Edward Elgar, p. 333-359

Bergek, A., Jacobsson, S., Carlsson, B., Lindmark, S., Rickne, A. (2008) Analyzing the functional dynamics of technological innovation systems: A scheme of analysis, Research Policy, 37 (3), 407-429.

Braun, D. (2008) Lessons on the political coordination of knowledge and innovation policies, Science and Public Policy 35: 289-298.

Boon, W. and Edler, J. (2018) Demand, challenges, and innovation. Making sense of new trends in innovation policy, Science and Public Policy, https://doi.org/10.1093/scipol/scy014

Daly, H. E. (2008). A steady state economy. Paper presented to the UK Sustainable Development Commission 24 April 2008, http://www.theoildrum.com/node/3941, consulted on 30.10.2017

Dietz, R. and D. O'Neill (2013) Enough Is Enough: Building a Sustainable Economy in a World of Finite Resources, San Francisco: Berret-Koehler Publishers

Dosi, G. (1982) Technological paradigms and technological trajectories: a suggested interpretation of the determinants and directions of technical change. Research Policy 11: 147-162

Edler, J. and Fagerberg, J. (2017) Innovation policy: what, why, and how, Oxford Review of Economic Policy 33 (1), 2-23.

Edler, J. and Georghiou, L. (2007) Public procurement and innovation - Resurrecting the demand side, Research Policy, 36 (7), 949-963.

Edquist, C. (2004). "Systems of Innovation: Perspectives and Challenges" in Fagerberg, J., Mowery, D., and Nelson, R (eds.) Oxford Handbook of Innovation, Oxford: Oxford University Press, p. 181-208

Edquist, C. (2011) Design of innovation policy through diagnostic analysis: Identification of systemic problems (or failures), Industrial and Corporate Change, 20 (6), 1-29.

Ergas, H. (1986) Does Technology Policy matter? CEPS papers No 29, Brussels, Centre for European Studies. 
Fagerberg, J. (2003) Schumpeter and the revival of evolutionary economics: an appraisal of the literature, Journal of Evolutionary Economics 13:125-159

Fagerberg, J. (2004) Innovation: A guide to the Literature, in Fagerberg, J., Mowery, D., and Nelson, R (eds.) The Oxford Handbook of Innovation, Oxford University Press, Oxford, 2004, p 1-26.

Fagerberg, J. (2016). Innovation Systems and Policy: A Tale of Three Countries, Stato e Mercato 36 (1), $13-40$

Fagerberg, J. (2017) Innovation Policy: Rationales, Lessons and Challenges, Journal of Economic Surveys 31(2), 497-512

Fagerberg, J. (2018) "Mission (im)possible? The role of innovation (and innovation policy) in supporting structural change \& sustainability transitions," Working Papers on Innovation Studies 20180216, Centre for Technology, Innovation and Culture, University of Oslo, https://ideas.repec.org/p/tik/inowpp/20180216.html

Fagerberg, J., Fosaas, M. and Sapprasert, K. (2012) Innovation: Exploring the knowledge base, Research Policy 41: 1132-1153

Fagerberg, J., Laestadius, S. and Martin, B.R. (2016) The Triple Challenge for Europe: The Economy, Climate Change, and Governance, Challenge, 59 (3): 178-204

Fagerberg, J., Mowery, D., and Nelson, R. eds. (2004) The Oxford Handbook of Innovation, Oxford: Oxford University Press

Fagerberg, J., Mowery, D. and Verspagen, B. (2009). The evolution of Norway's national innovation system, Science and Public Policy, 36: 431-444

Flanagan, K., Uyarra, E. and Laranja, M. (2011) Reconceptualising the 'policy mix' for innovation, Research Policy, 40 (5), 702-713.

Freeman, C. (1974). The Economics of Industrial Innovation, Harmondsworth: Penguin

Freeman, C. (1987) Technology policy and economic performance: Lessons from Japan, London: Pinter

Freeman, C., Clark, J. and Soete, L. G. (1982) Unemployment and Technical Innovation: a Study of Long Waves and Economic Development, London: Pinter

Freeman, C. and Louçã, F. (2001) As Time Goes By. From the Industrial Revolutions to the Information Revolution, Oxford: Oxford University Press

Freeman, C. and Perez, C. (1988) "Structural Crises of Adjustment: Business Cycles and Investment Behaviour", in Dosi, G., Freeman, C., Nelson, R.R., Silverberg, G. and Soete, L. G. (eds.), Technical Change and Economic Theory, London: Pinter, p. 38-66.

Geels, F. W. (2002) Technological transitions as evolutionary reconfiguration processes: a multi-level perspective and a case-study, Research Policy 31: 1257-1274

Geels, F. W. (2014) Regime Resistance against Low-Carbon Transitions: Introducing Politics and Power into the Multi-Level Perspective, Theory, Culture \& Society 31 (5): 21 - 40

Geels, F. W. (2015)The arduous transition to low-carbon energy: A multi-level analysis of renewable electricity niches and resilient regimes, in Fagerberg, J., S. Laestadius and B. R. Martin (2015) The Triple Challenge for Europe Economic Development, Climate Change and Governance, Oxford University Press, p. 91-118 
Geels, F. W. and J. Schot (2007) Typology of sociotechnical transition pathways, Research Policy 36: 399-417.

Goodall, C. (2016) The Switch: How solar, storage and new tech means cheap power for all, London: Profile Books

Grubler, A. (2012) Energy transitions research: Insights and cautionary tales, Energy Policy 50, 8-16

Hall, B.H. \& Rosenberg, N. eds. (2010) Handbook of the Economics of Innovation, Amsterdam: North Holland

Hendriks, C.M. (2009) Policy design without democracy? Making democratic sense of transition management, Policy Sciences 42: 341-368

Irena (2017) Renewable Energy and Jobs, Annual Review 2017,

http://www.irena.org/documentdownloads/publications/irena re jobs annual review 2017.pdf,

downloaded on August 21, 2017

Jacobsson, S., Sandén, B. and Bångemns, L. (2004) Transforming the Energy System-the Evolution of the German Technological System for Solar Cells, Technology Analysis \& Strategic Management 16:1, $3-30$

Kemp, R. (2011) Ten themes for eco-innovation policies in Europe, S.A.P.I.EN.S , 4 (2), 1-20

Kemp, R, Loorbach, D.A, \& Rotmans, J. (2007). Transition management as a model for managing processes of co-evolution towards sustainable development. The International Journal of Sustainable Development and World Ecology, 14(1), 78-91

Kemp, R. and B. Never (2017) Green transition, industrial policy, and economic development, Oxford Review of Economic Policy 33 (1), p. 66-84,

Kemp, R., Schot, J. and Hoogma, R. (1998) Regime shifts to sustainability through processes of niche formation: The approach of strategic niche management. Technology Analysis and Strategic Management 10(2): 175-198.

Kline, S.J. and Rosenberg, N. (1986) "An Overview of Innovation", in Landau, R. and Rosenberg, N. (eds.) The Positive Sum Strategy: Harnessing Technology for Economic Growth, Washington D.C.: National Academy Press, p. 275-304

Kuhlmann, S. and Rip, A. (2018) Next-Generation Innovation Policy and Grand Challenges, Science and Public Policy, https://doi.org/10.1093/scipol/scy011

Levin, R. C., A.K. Klevorick, R.R. Nelson and S.G. Winter (1987) 'Appropriating the Returns from Industrial Research and Development', Brookings Pap. Econ. Act: Microeconomics, p. 783-820.

Liu, X. and White, S. (2001) Comparing innovation systems: a framework and application to China's transitional context, Research Policy, 30 (7), 1091-1114

Loorbach, D. (2010) Transition Management for Sustainable Development: A Prescriptive, ComplexityBased Governance Framework, Governance: An International Journal of Policy, Administration and Institutions 23 (1), 161-183

Lundvall, B. A. (1988) Innovation as an Interactive Process: from User-Producer Interaction to the National System of Innovation, in Dosi, G. et al. (eds.), Technical Change and Economic Theory, London: Pinter, p. 349-369 
Lundvall, B. Å. (1992) National Systems of Innovation: Towards a Theory of Innovation and Interactive Learning, London: Pinter

Malerba, F. (2004) 'Sectoral Systems: How and why innovation differs across sectors', in Fagerberg, J., Mowery, D., Nelson, R. (eds.) The Oxford Handbook of Innovation, Oxford: Oxford University Press, pp. 380-406.

Mathews, J. A. (2013) The renewable energies technology surge: A new techno-economic paradigm in the making? In Futures 46, p. 10-22

Mathews, J. A. (2014). Greening of Capitalism: How Asia Is Driving the Next Great Transformation, Stanford: Stanford University Press.

Mazzucato, M. (2013) The entrepreneurial state: debunking private vs. public sector myths. Anthem Press, London, UK.

Mazzucato, M. (2016) From market fixing to market-creating: a new framework for innovation policy, Industry and Innovation, 23 (2), 140-156.

Mazzucato, M. (2017) Mission-Oriented Innovation Policy: Challenges and Opportunities, London: RSA,https://www.thersa.org/globalassets/pdfs/reports/mission-oriented-policy-innovationreport.pdf, addressed on 30.11.2017

Mazzucato, M. and C. Perez (2015) Innovation as Growth Policy: the Challenge for Europe, in Fagerberg, J., S. Laestadius and B. R. Martin (2015) The Triple Challenge for Europe: Economic Development, Climate Change and Governance, Oxford University Press, p. 229-264

Mee Lie, C. (2017) Does green growth require a different type of policies? Exploring four recent policy frameworks, Centre for Technology, Innovation and Culture, University of Oslo

Metcalfe, J. S. (2005) Systems Failure and the Case for Innovation Policy, in Llerena, P. and Matt, M. (eds.) Innovation Policy in a Knowledge-Based Economy: Theory and Practice, Heidelberg: Springer, pp. 47-74.

Mowery, D.C., R.R. Nelson and B.R. Martin (2010). 'Technology Policy and Global Warming: Why New Policy Models are Needed (Or Why Putting New Wine in Old Bottles Won't Work)', Research Policy, 39, pp.1011-1023.

Mowery, D.C. (2011), Federal Policy and the Development of Semiconductors, Computer Hardware and Computer Software: A Policy Model for Climate Change R\&D?, in Rebecca M. Henderson and Richard G. Newell (eds), Accelerating Energy Innovation: Insights from Multiple Sectors, Chapter 5, Chicago, IL: University of Chicago Press, 159-88

Nelson, R. R. (ed.) (1993) National Innovation Systems: A Comparative Study, Oxford: Oxford University Press.

Nelson, R. R. and Winter, S. G. (1982) An Evolutionary Theory of Economic Change, Cambridge, Mass: Harvard University Press

Nill, J. and R. Kemp (2009) Evolutionary approaches for sustainable innovation policies: From niche to paradigm? Research Policy 38 (4), 668-680

OECD (1997) National Innovation Systems, Paris: OECD.

OECD (1999) Managing National Innovation Systems, Paris: OECD. 
OECD (2002) Dynamising National Innovation Systems, Paris: OECD.

OECD (2010a) The OECD Innovation Strategy: getting a head start on tomorrow, Paris: OECD Publishing.

OECD (2010b) 'The Innovation Policy Mix', in OECD (ed.), OECD Science, Technology and Industry Outlook 2010, Paris: OECD, pp. 251-279.

Ostrom, E. (2010) Polycentric systems for coping with collective action and global environmental change, Global Environmental Change, 20 (4), 550-557

Pelkonen, A. (2006) The problem of integrated innovation policy: Analysing the governing role of the science and technology policy council of Finland, Science and Public Policy 33(9): 669-680.

Perez, C. (2002) Technological Revolutions and Financial Capital: The Dynamics of Bubbles and Golden Ages, Cheltenham: Edward Elgar

Perez, C. (2016) Capitalism, Technology and a Green Global Golden Age: The Role of History in Helping to Shape the Future, in Jacobs, M. and Mazzucato. M. (eds.) Rethinking Capitalism: Economics and Policy for Sustainable and Inclusive Growth, The Political Quarterly, Chichester: Wiley-Blackwell, p. 191-207

Pearson, P. J. G. and Foxon, T.J. (2012) A low carbon industrial revolution? Insights and challenges from past technological and economic transformations, Energy Policy 50, 117-127

Rip, A. and Kemp, R. (1998) Technological change, in Rayner, S. and Malone, E. L. (eds.) Human choice and climate change, vol. 2, Resources and technology, Washington D.C.: Battelle Press, pp. 327-399.

Rodrik, D. (2014) Green industrial policy, Oxford Review of Economic Policy 30 (3), 469-491

Rosenberg, N. (1990). Why Do Firms Do Basic Research (with Their Own Money), Research Policy 19(2):165-174.

Rothwell, R. (1982) Government innovation policy: Some past problems and recent trends, Technological Forecasting and Social Change, 22 (1), 3-30.

Rotmans, J., Kemp, R. and van Asselt, M. (2001) More evolution than revolution: Transition management in public policy, Foresight 3(1), 15-31.

Rothwell, R. (1982) Government innovation policy: Some past problems and recent trends, Technological Forecasting and Social Change, 22 (1), 3-30.

Schmitz, H. (2015) Green Transformation: Is There a Fast Track?, in I. Scoones, M. Leach, P. Newell (eds.), The Politics of Green Transformations, London: Routledge

Schmitz, H. and R. Lema (2015). 'The Global Green Economy: Competition or Cooperation between Europe and China?', in Fagerberg, J., S. Laestadius and B. R. Martin (2015), The Triple Challenge for Europe: Economic Development, Climate Change and Governance, Oxford: Oxford University Press, pp.119-142

Schot, J and. W. E. Steinmueller (2018) Three Frames for Innovation Policy: R\&D, Systems of Innovation and Transformative Change, Research Policy (this issue)

Schumpeter, J. A. (1934) The Theory of Economic Development, Cambridge, Mass: Harvard University Press. 
Schumpeter J. A. (1939) Business cycles: a theoretical historical and statistical analysis of the capitalist process (2vol). New York: McGraw-Hill

Schumpeter, J. A. (1942) Capitalism, Socialism and Democracy, New York: Harper.

Seba, T. (2014) Clean Disruption of Energy and Transportation: How Silicon Valley Will Make Oil, Nuclear, Natural Gas, Coal, Electric Utilities and Conventional Cars Obsolete by 2030, Silicon Valley, California: Clean Planet Ventures

Serger, S.S., Wise, E. and Arnold, E. (2015) National Research \& Innovation Councils as an Instrument of Innovation Governance: Characteristics and Challenges. Vinnova Analysis VA 2015:07. Stockholm: Vinnova

Smil, V. (2016) Examining energy transitions: A dozen insights based on performance. Energy Research \& Social Science 22:194-197

Smith, A. \& F. Kern (2009) The transitions storyline in Dutch environmental policy, Environmental Politics 18 (1), 78-98

Smith, A., Voss, J.-P. and Grin, J. (2010) Innovation studies and sustainability transitions: The allure of the multi-level perspective and its challenges. Research Policy, 39 (4), 435-448

Smith, K. (2004) "Measuring Innovation" in Fagerberg, J., Mowery, D., Nelson, R. (eds.), The Oxford Handbook of Innovation, Oxford: Oxford University Press, p. 148-178

Smith, K. (2017) Innovating for the global commons: multilateral collaboration in a polycentric world, Oxford Review of Economic Policy, Volume 33, Issue 1, Pages 49-65

Smits, R. and Kuhlmann, S. (2004). The rise of systemic instruments in innovation policy, International Journal of Foresight and Innovation Policy 1: 4-32

Soete, L. and A. Arunddel (1993) An Integrated Approach to European Innovation and Technology Diffusion Policy: A MAASTRICHT MEMORANDUM, Commission of the European Communities, Dissemination of Scientific and Technical Knowledge Unit, Directorate-General Information Technologies and Industries, and Telecommunications, Luxembourg

Sovacool, B.K. (2016) How long will it take? Conceptualizing the temporal dynamics of energy transitions, Energy Research \& Social Science 13, 202-215

Stern, N. (2015) Why are We Waiting?: The Logic, Urgency, and Promise of Tackling Climate Change, The MIT Press

Steward, F. (2012) Transformative innovation policy to meet the challenge of climate change: sociotechnical networks aligned with consumption and end-use as new transition arenas for a lowcarbon society or green economy, Technology Analysis \& Strategic Management Vol. 24 (4), 331-343

van den Bergh J.C.J.M., Truffer B. and Kallis G. (2011) Environmental innovation and societal transitions: Introduction and overview, Environmental Innovation and Societal Transitions 1 (1), 1-23

von Hippel, E. (1988) The Sources of Innovation, New York: Oxford University Press.

von Hippel, E. (1994) "Sticky Information" and the Locus of Problem Solving: Implications for Innovation, Management Science, 40 (4), 429-439.

von Hippel, E. (2005) Democratizing Innovation, Cambridge, MA: MIT Press 
Voss, J.P., Smith, A. and Grin, J. (2009) Designing long-term policy: rethinking transition management, Policy sciences $42(4), 275-302$

Weber, K. M. and Rohracher, H. (2012) Legitimizing research, technology and innovation policies for transformative change, Research Policy 41 (6), 1037-1047

Wilson, C. (2012) Up-scaling, formative phases, and learning in the historical diffusion of energy technologies, Energy Policy 50: 81-94

Winter, S. G. (1984) Schumpeterian competition in alternative technological regimes. Journal of Economic Behavior and Organization 5: 287-320 